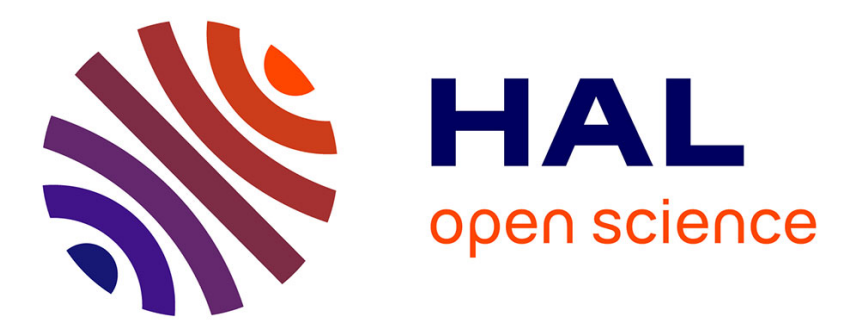

\title{
Difference in responses of two coastal species to fluctuating salinities and temperatures: Potential modification of specific distribution areas in the context of global change
}

Thomas Trancart, Eric Feunteun, Christel Lefrançois, Anthony Acou, Christophe Boinet, Alexandre Carpentier

\section{To cite this version:}

Thomas Trancart, Eric Feunteun, Christel Lefrançois, Anthony Acou, Christophe Boinet, et al.. Difference in responses of two coastal species to fluctuating salinities and temperatures: Potential modification of specific distribution areas in the context of global change. Estuarine, Coastal and Shelf Science, 2016, 173, pp.9-15. 10.1016/j.ecss.2016.02.012 . hal-01281455

HAL Id: hal-01281455

https://hal-univ-rennes1.archives-ouvertes.fr/hal-01281455

Submitted on 4 Apr 2016

HAL is a multi-disciplinary open access archive for the deposit and dissemination of scientific research documents, whether they are published or not. The documents may come from teaching and research institutions in France or abroad, or from public or private research centers.
L'archive ouverte pluridisciplinaire HAL, est destinée au dépôt et à la diffusion de documents scientifiques de niveau recherche, publiés ou non, émanant des établissements d'enseignement et de recherche français ou étrangers, des laboratoires publics ou privés. 


\title{
Difference in responses of two coastal species to fluctuating salinities and temperatures: potential modification of specific distribution areas in the context of global change
}

\author{
Thomas Trancart*a,b, Eric Feunteun ${ }^{\mathrm{a}, \mathrm{b}}$, Christel Lefrançois ${ }^{\mathrm{c}}$, \\ Anthony Acou ${ }^{\mathrm{a}, \mathrm{b}}$, Christophe Boinet ${ }^{\mathrm{b}}$, Alexandre Carpentier ${ }^{\mathrm{b}, \mathrm{d}}$ \\ * Corresponding author \\ ${ }^{\text {a} U M R ~ B O R E A ~-~ M N H N, ~ C N R S ~ 7208, ~ U P M C, ~ I R D ~ 207, ~ U C B N, ~ P a r t e n a i r e ~}$ \\ UAG \\ ${ }^{\mathrm{b}}$ Station Marine de Dinard, 38 Rue du Port Blanc, F-35800 Dinard, France \\ ${ }^{c}$ LIENSs UMR7266 (CNRS-Univ. La Rochelle) Inst Littoral \& Environm, F- \\ 17042 La Rochelle, France \\ ${ }^{\mathrm{d} U n i v e r s i t e ́ ~ d e ~ R e n n e s ~ 1, ~ E A ~ 7316, ~ C a m p u s ~ d e ~ B e a u l i e u, ~ F-35042 ~ R e n n e s ~ C e d e x, ~}$ \\ France
}

\begin{abstract}
In the past several years, all numerical models have forecasted an increase in extreme climatic events linked to global change. Estuarine waters at the interface of marine and freshwater bodies are among the most volatile ecosystems, particularly for aquatic species, and will be strongly influenced by the temperature with extreme flooding events. This study aimed to quantify the acclimation capacity of coastal fish species to estuarine plume modifications. The thicklip mullet (Chelon labrosus) and European seabass (Dicentrarchus labrax) were selected as representative species of estuarine ecological guilds. These fish were subjected to an experiment mimicking a brief freshwater intrusion (35-5). These experiments were conducted at two different temperatures that these two species would encounter during their incursion from the sea through estuarine waters to freshwater habitats. The experimental results confirmed the high capacity for acclimation of both species to changes in salinity and temperature. Interspecific differences were observed. For example, the salinity has a greater effect on the metabolism of the seabass than on that of the mullets. Meanwhile, the temperature has a greater effect on the mullets. These differences in metabolic responses to fluctuating salinities and temperatures may modify the use of estuarine waters by these species and should be considered when predicting future specific distribution areas in the context of global change.
\end{abstract}


Keywords:

Swim tunnels; oxygen consumption; swimming respirometry; conservation; physiology; Chelon labrosus; Dicentrarchus labrax

\section{INTRODUCTION}

Most studies on the impact of climate change on aquatic ecosystems have usually focused on the most visible aspect of global warming: the increase in mean water temperature and drought frequencies. However, according to the scenarios developed by the Intergovernmental Panel on Climate Change (IPCC, 2014), an increase in the magnitude and frequency of flood events is also expected. Risks from extreme events, such as heat waves, extreme precipitation, and coastal flooding, are already accentuated with an additional warming of $1{ }^{\circ} \mathrm{C}$ (IPCC), 2014) and will undoubtedly get worse in the coming years. In a large continental integrated analysis, Lehner et al. (2006) showed that the areas most prone to a rise in flood frequencies are northern and northeastern Europe.

Freshwater plumes have a considerable physical impact on marine areas. The influence of plumes from an average river system (e.g. Adour in France, which has a mean flow of $350 \mathrm{~m}^{3} \mathrm{~s}^{-1}$ ) can reach $20 \mathrm{~m}$ in depth and over 15$20 \mathrm{~km}$ in horizontal distance (Ferrer et al. 2009 ). However, the influence can be much greater. For example, the source of the low-salinity surface waters in the western English Channel is the plumes from the Loire and Gironde Rivers, which are located several hundred kilometres away along the French Atlantic coast (Kelly-Gerreyn et al., 2006). There is also considerable biological interest in freshwater plumes. For numerous marine species along the east Atlantic coast, nurseries are located in coastal, tidal, or estuarine areas and are likely to be influenced by plumes (Jenkins et al., 1997; Le Pape et al., 2003; Rochette et al. 2010). Because of their higher productivity, nurseries can be considered to be more favourable for the development and growth of young fish stages Able, 
1999, Gibson, 1994, Grover et al. 2002, Holbrook et al., 2000, Peterson, 2003).

For instance, in the Couesnon estuary (France), periodic sampling at different seasons has shown high fish diversity (28 different species), with a majority of the species represented by post-larvae and juveniles stages (Laffaille et al., 2001b). The higher biological favourability of these nurseries can be explained by several factors, such as the prey diversity (Miller et al., 1984), higher temperature (Macpherson and Duarte, 1991), and lesser predation pressure (Ruiz et al. 1993).

Global changes would increase the unpredictability of plumes and strongly modify numerous coastal abiotic factors that depend on freshwater inputs, such as the temperature, salinity, concentration of suspended matter, oxygen concentration (linked with temperature and salinity), and concentration of pollutants. These modifications may favour the use of estuarine habitats by very plastic species with great adaptability to changes in salinity, such as the euryhaline wanderer and catadromous species (McDowall, 1987, 1988).

Although there are about 200 European estuarine fish species (Elliott and Dewailly, 1995), the assemblages are often reduced and limited to the same main species (Nicolas et al., 2010, Maitland and Lyle, 1991). These species are divided into different ecological guilds (Elliott and Dewailly, 1995), including marine seasonal migrants and marine juvenile migrants likely to be able to cope with tidal salinity changes. Such migratory behaviour would be an advantage for them to reach highly productive habitats with lower interspecific competition. The question is how such species can adapt to the increasing unpredictability of plumes. In this context, the aim of this study was to experimentally compare the physiological abilities of species from these two guilds to cope with the large range of salinity observed in estuaries, from euhalin (more of 30) to oligohalin (0-5) waters, at two different temperatures. 
The European seabass Dicentrarchus labrax is one of the most numerous of species in estuaries (Nicolas et al. 2010) and is described as a marine juvenile migrant (Elliott and Dewailly, 1995). This species is very common and widespread along European and North African coastal areas. The top piscivorous predator (Kottelat, 2008), it exploits both coastal and shallow waters (Pickett and Pawson, 1996; Sanchez Vazquez and Munoz-Cueto, 2014) and for this reason is usually described as euryhaline fish species. Each year, young seabass colonise supratidal and intertidal marsh creeks and subtidal and intertidal flats to feed (Laffaille et al., 2001a). Grey mullets, although less abundant in estuaries (Nicolas et al. 2010), also have a key role and are described as marine seasonal migrants.

There is no clear consensus on the catadromous character of mullets. According to McDowall (1997), the main differences between a catadromous and euryhaline wanderer species is the frequency of freshwater incursion. Euryhaline wanderers perform occasional incursions in freshwater to feed, while catadromous species make regular migrations and complete their adult growth in freshwater. Thinlip mullets (Liza ramada) have classically been the only species of mullets designated as catadromous (Kottelat, 2008). Others species of grey mullets, like Mugil cephalus, Chelon labrosus, Liza aurata, and L. saliens, are also sometimes considered to be marine migrants (Franzoi et al., 2010) with cyclical migrations between marine coastal areas and transitional waters. Grey mullets are the only fish species able to exploit the great productivity of the biofilm in intertidal areas and probably play an important ecological role in $\mathrm{C}$ transfer from inter- to sub-tidal areas (Carpentier et al., 2014).

These two fish species are undoubtedly strongly linked to estuarine and/or coastal low salinity waters. In particular, adults and juveniles European seabass perform daily tidal migrations from marine to estuarine waters for feeding (Laf- 
faille et al. 2001a; Kelley et al., 1987; Pawson et al., 1987). A lack of study and knowledge about thicklip mullets Chelon labrosus has led to no clear evidence for them having similar behaviour, but their presence during flood tides and at low salinity in several estuaries and marshes supports this hypothesis (Gautier and Hussenot, 2005, Lasserre and Gallis, 1975, Nicolas et al., 2010. Feunteun et al. 1999). According to the literature, these two species have similar osmoregulation capacity (Gautier and Hussenot, 2005, Sanchez Vazquez and Munoz-Cueto, 2014 despite belonging to different ecological guilds; thus, their specific responses to salinity and temperature and by extension to climate change can be contrasted.

Previous studies have already analysed the impact of salinity and temperature variations on fish metabolism by mimicking the characteristics of coastal waters influenced by plume. A large range of patterns has been observed. Longterm experiments were performed on European seabass juveniles in swim tunnels to monitor the effect of changes in the salinity on the critical speed, cardiac performance, and oxygen consumption during exercise. These are considered a proxy of the global metabolism and are thus called $\mathrm{MO}_{2}$. No significant effects were observed after $18 \mathrm{~h}$ of exposure to freshwater (Chatelier et al., 2005), which confirmed the high plasticity of this species. In contrast, the number of feeding events and swimming activity of the golden grey mullet (Liza aurata) were found to increase with the water temperature (Como et al. 2014). Although described as euryhaline, thicklip mullets (Chelon labrosus) cannot live for long periods of time in entirely freshwater habitats (Lasserre and Gallis, 1975). The inability of thicklip mullets to develop long-term hypo-osmoregulation in freshwater probably limits the upstream penetration of this species (Lasserre and Gallis, 1975). In brackish water (15), the growth of thicklip mullets is not affected (Cardona et al. 2008), which suggests that this species also has high plasticity. 
In the present study, an experiment was performed to mimic an incursion into a freshwater plume over one tide (i.e. about $6 \mathrm{~h}$ ), which is a common pattern for thicklip mullet (Chelon labrosus) and European seabass (Dicentrarchus labrax) individuals in northwestern European coastal actchements (Laffaille et al. 2001a). The variability in responses of both fish species' metabolism to short-term salinity variations at different temperatures was compared. The current mean water temperature in the estuaries of the Bay of Biscay during the main feeding period of these species (April-May) was selected as a reference temperature $\left(17^{\circ} \mathrm{C}\right)$, and a second temperature corresponding to the observed warm peak in the above region over the same period $\left(21^{\circ} \mathrm{C}\right)$ was also selected. Based on the known plasticity of the two species to salinity and temperature, contrasting results in terms of the metabolism responses were hypothesised. The expectation was to obtain some keys to better anticipating how these species and thus the guilds they represent will react to the increasing unpredictability of coastal fluvial plumes, which is expected in the next decades as a consequence of global warming.

\section{MATERIAL AND METHODS}

\subsection{Fish collection, acclimation, and stress removal}

Twelve adult or sub-adult thicklip grey mullets (Chelon labrosus) were caught with a fishing rod at the mouth of the Rance estuary near Saint-Malo (northwestern France) in November 2014. Twelve adult or sub-adult European seabass (Dicentrarchus labrax) were bought from a fish farm at the mouth of the Auray estuary near Vannes (northwestern France) in November 2014. The two collection sites were located in euhaline waters. After sampling, the fish were anaesthetised with $40 \mathrm{mg} . \mathrm{l}^{-1}$ of a benzocaine (ethyl 4-aminobenzoate) solution, measured, and individually tagged. For the mullets, the total length (TL) ranged 
from $348 \mathrm{~mm}$ to $445 \mathrm{~mm}($ mean $=395 \mathrm{~mm})$, and the body weight $(\mathrm{BW})$ ranged from $456 \mathrm{~g}$ to $1145 \mathrm{~g}$ (mean $=744 \mathrm{~g}$ ). For the seabass, the TL ranged from $400 \mathrm{~mm}$ to $450 \mathrm{~mm}($ mean $=420)$, and the body weight $(\mathrm{BW})$ ranged from 813 $\mathrm{g}$ to $1130 \mathrm{~g}($ mean $=986 \mathrm{~g})$. The fish were placed in 800-l acclimation tanks (three conspecific fish per tank) with water directly pumped from the sea and kept under natural light. The water temperature was set at $17{ }^{\circ} \mathrm{C}$, as in field during the fish collection, and the water was filtered $(10 \mu \mathrm{m})$ and UV-sterilised.

In such an experiment, it is essential to avoid handling and experimental stress. The effect from stress should be removed so that only the effects of the studied variables need to be considered. To remove the experimentation bias, special care was taken in the present study. First, the fish were anaesthetised in their acclimation tank before being transferred to the tunnels. Second, during transfer to the tunnels, the fish were permanently kept in water; for this, the tunnels were slightly inclined when opened in order to keep enough water in the tunnels so that the fish could stay completely immersed. Finally, the experiments were conducted in a dark room without human presence. The fish were monitored with infrared cameras.

\subsection{Swim tunnel setup and $\mathrm{O}_{2}$ consumption}

These experiments were based on the closed respirometry principle; the water in the swim tunnels was not replaced during the oxygen decline measurement. The decline in $\mathrm{O}_{2}$ in each swim tunnel was then measured continuously $(1 \mathrm{~Hz})$ with an $\mathrm{O}_{2}$ electrode (Loligo Systems, Tjele, Denmark). One disadvantage was that the measurements were not taken at a constant oxygen level due to the continuous use of oxygen by the animal inside the swim tunnel. To remove this bias, the $\mathrm{O}_{2}$ decline was limited at various levels depending on the experimental temperature to stay above $50 \%-60 \%$ air saturation. Below this value, the water 
was renewed in the swim tunnel and therefore re-oxygenated; the experiment was then stopped. The temperature probe in the swim tunnels was linked to the Loligo software (WitroxView) to ensure automatic temperature adjustment (precision: $\pm 0.1{ }^{\circ} \mathrm{C}$ ). The atmospheric pressure and water salinity were noted for automatic adjustment in the acquisition software. The $\mathrm{O}_{2}$ consumption $\left(\mathrm{MO}_{2}\right)\left(\mathrm{mg} \mathrm{O}_{2} \mathrm{~kg}^{-1} \mathrm{~h}^{-1}\right)$ was calculated from the $\mathrm{O}_{2}$ concentration decline in the absence of water renewal in the swim tunnel as follows:

$$
M O_{2}=\frac{V \times \Delta\left[O_{2}\right]}{W \times \Delta t}
$$

where $\Delta\left[O_{2}\right]$ is the observed $\mathrm{O}_{2}$ change in concentration $\left(\mathrm{mg} \mathrm{O}_{2} \mathrm{l}^{-1}\right), V$ is the volume in the swim tunnel (l), $W$ is the body weight of the experimented fish $(\mathrm{kg})$, and $\Delta t$ is the time spent in the absence of water renewal (h). To remove the technical bias associated with the electrodes (precision: $\pm 0.1 \%$ ), a high acquisition frequency $(1 \mathrm{~Hz})$ and moving average (5 min, i.e. 300 observations on average) of the $\mathrm{O}_{2}$-concentration was used to calculate the changes.

\subsection{Experimental protocols}

The experimental protocol was designed to mimic a brief incursion in freshwater, which is a frequent supposed behaviour (Figure 1). Three fish were simultaneously tested individually in three swim tunnels. The three fish from an acclimation tank were anaesthetised by the addition of benzocaine (ethyl 4-aminobenzoate, final concentration in tank: $40 \mathrm{mg} \cdot \mathrm{l}^{-1}$ ) at 16:00 the day before the experiment. The fish were then individually transferred into one of the three similar swimming respirometers (Blazka-type 127-l swim tunnels designed by Leiden University, the Netherlands, and described by van den Thillart et al. (2004)).

The swim tunnels were closed and filled with aerated marine water at a 
constant temperature and salinity $\left(16-17^{\circ} \mathrm{C}\right.$ and $34-35$, respectively). Light in the experimental room was turned off to minimise the stress. After the total elimination of the anaesthetising effect (recovery of locomotor movement, generally in 10-15 $\mathrm{min}$ ), the water velocity was set at 0.4 body length $\mathrm{s}^{-1}$, i.e. 10 times below the burst speed for these species (Blaxter, 1969; Nelson and Claireaux, 2005). The fish were kept in tunnels under these conditions until 08:00 the day after. The temperature was then carefully adjusted to the target temperature (either 17 or $21^{\circ} \mathrm{C} \pm 0.1{ }^{\circ} \mathrm{C}$ ).

When the temperature was reached, the oxygen concentration was first measured over $2 \mathrm{~h}$ (recording frequency: $1 \mathrm{~Hz}$ ) in marine water (34-35). The salinity was then decreased to 5 over $1 \mathrm{~h}$ by the addition of freshwater, and the oxygen concentration was again measured over $2 \mathrm{~h}$ (recording frequency: $1 \mathrm{~Hz}$ ). Finally, the salinity was increased to the initial salinity $( \pm 1-2)$ over $1 \mathrm{~h}$ by the addition of marine water. The oxygen concentration was again measured for 2 $\mathrm{h}$ (recording frequency: $1 \mathrm{~Hz}$ ). This protocol was repeated at 17 and $21{ }^{\circ} \mathrm{C}$ for each fish. The two temperatures were alternated in order to remove potential temporal bias, and the fish were always placed in the same tunnel to remove the potential tunnel effect. Oxygen was monitored for $2 \mathrm{~h}$ in each of the three recording periods, except when the oxygen concentration decreased below the critical level, i.e. $50 \%-60 \%$ air saturation. In this case, the monitoring was stopped, and the water was re-oxygenated.

\subsection{Statistics}

The instantaneous oxygen consumption $\left(\mathrm{mg} \mathrm{O}_{2} \mathrm{l}^{-1} 5 \mathrm{~min}^{-1}\right)$ was used to determine the steady period, which was assumed to have no or little stress. A steady period was defined as one with $\mathrm{MO}_{2}$ variations under $10 \%$ of the mean $\mathrm{MO}_{2}$. The experiment was designed in order to limit the number of fish required 


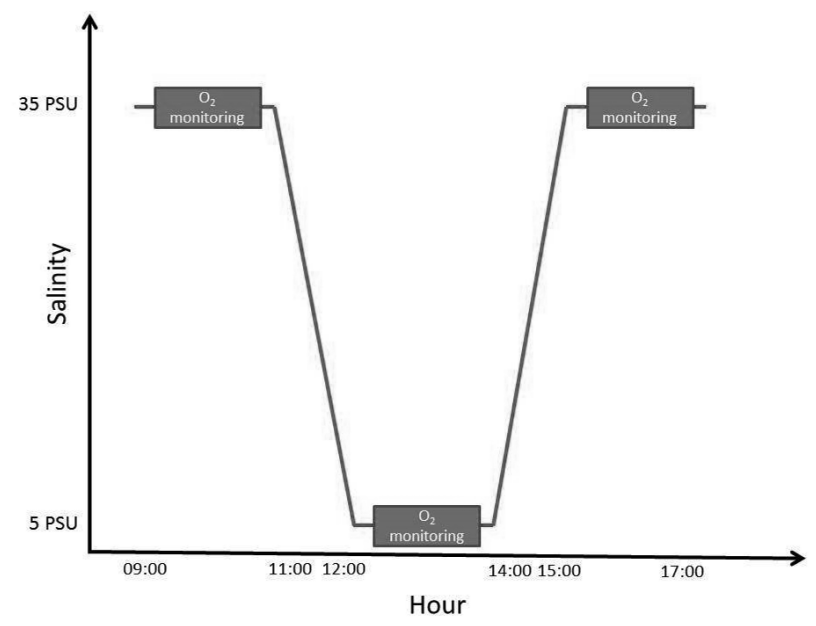

Figure 1: Scheme of the experiment mimicking a brief freshwater intrusion (35-5). Solid line: water salinity change. Grey squares: period of oxygen logging

by using the repeated measures approach. First, a repeated measure ANOVA (GLM with Gaussian family, Pillai test) with salinity and temperature as the within and between factors, respectively, was run to identify the significance of the influence of these variables on $\mathrm{MO}_{2}$. The differences between the modalities of each factor (post-hoc test) were highlighted with pairwise comparison (Pillai test, Holm adjustment). Second, a three-way ANOVA (GLM with Gaussian family) with salinity, temperature, and species as factors was run to identify specific differences between the mullets and seabass. For each model, the homoscedasticity was visually checked (QQ-plot and histograms of residuals). All of the models were fitted by using the R language \environment Tea (2011). 


\section{RESULTS}

\subsection{Global values of $\mathrm{MO}_{2}$}

The average $\mathrm{MO}_{2}$ for each experimental combination of the temperature and salinity are summarised in Table 1.

Table 1: Mean individual oxygen consumption $\mathbf{M O}_{2} \pm$ standard deviation ( $\mathrm{mg} \mathrm{O} \mathrm{O}_{2} \mathrm{~kg}^{-1} \mathrm{~h}^{-1}$ ) measured for the two species experiencing 35 water, 5 water, and return to 35 (second) at 17 and $21{ }^{\circ} \mathrm{C}$.

\begin{tabular}{|l|l|l|l|l|}
\hline & Temp & 35 & 5 & 35 (second) \\
\hline \multirow{2}{*}{ Mullets } & $17^{\circ} \mathrm{C}$ & $144.07+/-24.14$ & $158.45+/-22.89$ & $138.60+/-26.28$ \\
& $21^{\circ} \mathrm{C}$ & $154.55+/-21.10$ & $166.22+/-22.13$ & $154.54+/-19.38$ \\
\hline \multirow{2}{*}{ Seabass } & $17^{\circ} \mathrm{C}$ & $174.3+/-25.38$ & $206.17+/-36.00$ & $182.6+/-25.38$ \\
& $21^{\circ} \mathrm{C}$ & $193.42+/-29.03$ & $228.9+/-41.08$ & $193.7+/-44.72$ \\
\hline
\end{tabular}

\subsection{Factors influencing $\mathrm{MO}_{2}$}

A similar pattern was observed for both the mullets and seabass; $\mathrm{MO}_{2}$ at 5 was almost always greater than that in marine water (see Fig. 2 and Tables 1, 3, and 5).

For the thicklip mullets, the two-way ANOVA showed that the salinity had a strong and significant effect (Gaussian model, Type III) (Table 2). The salinity was observed to have a similar effect on $\mathrm{MO}_{2}$ for the European seabass (Table $4)$.

A pairwise comparison (Pillai test, Holm adjustment method) showed the differences between the first measurement of $\mathrm{MO}_{2}$ at 35 and the measurement at 5 and between the second measurement of $\mathrm{MO}_{2}$ at 35 and the measurement at 5 for thicklip mullets (Table 3 ). 

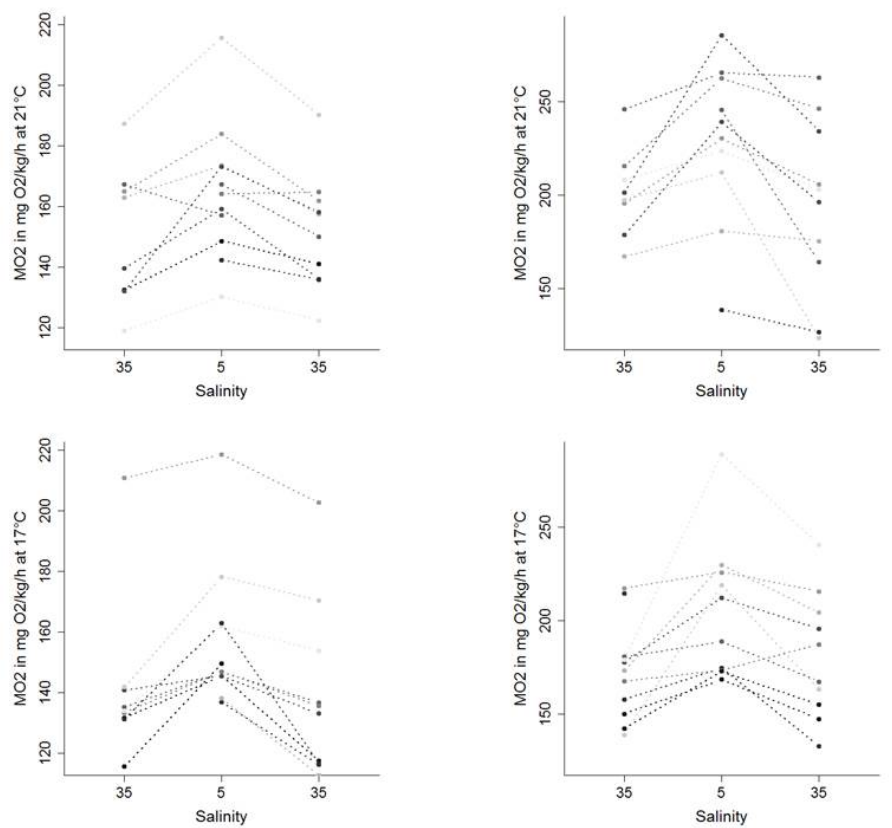

Figure 2: Individual changes in $\mathrm{MO}_{2}$ between 35 and 5 at $21{ }^{\circ} \mathrm{C}$ (top) and $17{ }^{\circ} \mathrm{C}$ (bottom) for thicklip mullets (left) and European seabass (right). Each line represents one individual.

Table 2: Effects of simulated factors on $\mathbf{M O}_{2}$ of the thicklip mullets (two-way repeated measure ANOVA)

\begin{tabular}{llll} 
Factor & Df & F & p-value \\
\hline Sal & 10 & 23.94 & $1.5 \times 10^{-04}$ \\
Temp & 11 & 5.59 & 0.03 \\
Sal:Temp & 10 & 1.65 & 0.24 \\
\hline
\end{tabular}

The temperature only had an effect on mullets (Table 2): $\mathrm{MO}_{2}$ was greater at $21^{\circ} \mathrm{C}$ than at $17^{\circ} \mathrm{C}$ (Table 3). A two-way ANOVA (Gaussian model, Type III) showed that his variable had no influence on $\mathrm{MO}_{2}$ of the seabass (Table 4). Finally, no interactive effect was observed between the temperature and salinity for either the mullets or seabass (Tables 2 and 4 ). 
Table 3: Factor pairwise comparison for thicklip mullets

\begin{tabular}{llll} 
Pairwise factors & Value & Df & p-value \\
\hline $35-35(2)$ & 2.77 & 11 & 0.53 \\
$35-5$ & -13.02 & 11 & $8.2 \times 10^{-03}$ \\
$35(2)-5$ & -15.79 & 11 & $1.4 \times 10^{-04}$ \\
$17^{\circ} \mathrm{C}-21^{\circ} \mathrm{C}$ & -11.38 & 11 & $3.7 \times 10^{-02}$ \\
\hline
\end{tabular}

Table 4: Effects of simulated factors on $\mathbf{M O}_{2}$ of the European seabass (two-way repeated measure ANOVA)

\begin{tabular}{llll}
\hline Factor & Df & F & p-value \\
\hline Sal & 8 & 16.81 & $1.3 \times 10^{-03}$ \\
Temp & 9 & 1.61 & 0.23 \\
Sal:Temp & 8 & 1.79 & 0.22 \\
\hline
\end{tabular}

Table 5: Factor pairwise comparison for European seabass

\begin{tabular}{lcll}
\hline Pairwise factors & Value & Df & p-value \\
\hline $35-35(2)$ & -2.83 & 9 & 0.68 \\
$35-5$ & -32.58 & 9 & $1.2 \times 10^{-03}$ \\
$35(2)-5$ & -29.75 & 9 & $2.0 \times 10^{-03}$ \\
$17^{\circ} \mathrm{C}-21^{\circ} \mathrm{C}$ & -18.56 & 9 & 0.23 \\
\hline
\end{tabular}

\subsection{Interspecies comparison}

$\mathrm{MO}_{2}$ was significantly higher in the seabass than in the mullets (Table 6). The seabass were more reactive to low salinity than the mullets (Table 6). Conversely, the rise in temperature had a greater effect on the mullets than on the seabass (Table 6). 
Table 6: Interspecific effects of factors influencing $\mathbf{M O}_{2}$

\begin{tabular}{llll} 
Factor & Df & Df resid & p-value \\
\hline Species & 1 & 137 & $<2.2 \times 10^{-16}$ \\
Interaction (Sal:species) & 4 & 133 & $1.9 \times 10^{-04}$ \\
Interaction (Temp:species) & 2 & 131 & $1.1 \times 10^{-02}$ \\
\hline
\end{tabular}

\section{DISCUSSION}

To the best of the authors' knowledge, this is the first time that the interactive effect of temperature and salinity on metabolism has been studied for mullets and adult seabass. The present study highlighted four main points, which are discussed below.

The change in salinity was designed to mimic a brief incursion from coastal seawater within the estuarine plume over one tide (i.e., about $6 \mathrm{~h}$ ). Such tidal migrations from marine to estuarine waters may regularly be performed by grey mullets (Liza spp.) and European seabass. First, at both target temperatures (17 and $21^{\circ} \mathrm{C}$ ), a significant increase in the oxygen consumption was measured as a response to the salinity drop: c.a. $19 \%$ for the European seabass and only about $12 \%$ for the thicklip mullets. This response to a change in salinity was not observed in a previous experiment with European seabass (Chatelier et al. $2005)$, but their acclimation time to low salinity (18 h) was much longer than that in the present study. This suggests that the ability of seabass to reduce the impact of salinity changes after $4 \mathrm{~h}$ (the present study) to a nonsignificant level after only $18 \mathrm{~h}$ (Chatelier et al., 2005). This fast acclimation ability appears to be a key skill for these euryhaline wanderers. For thicklip mullets, no similar previous physiological study was found to corroborate the present highlights.

The results highlight the low energetic costs of freshwater intrusions for these species, which suggests efficient osmoregulation capacities. These two species 
are capable of fine-tuning their responses to brutal changes in salinity mimicking a brief incursion from the sea to oligohaline brackish waters and vice versa. The absence of differences between the two in marine water (before and after the freshwater intrusion) reinforce this conclusion; the return to the initial state of metabolism was very fast. However, the results from the inter-species GLM suggest that the seabass is less tolerant than thicklip mullets to incursions into low-salinity habitats.

Interestingly, the results show that $\mathrm{MO}_{2}$ of the mullets responded to an increase in temperature. Conversely, the oxygen consumption of the seabass did not change significantly with temperature variations. This contrasts with the results of previous studies showing a strong increase in the metabolic rate for seabass experiencing a temperature decrease (e.g. Dalla Via et al., 1998). However, this can be assumed to be due to the extremely large range of temperature used $\left(10-30{ }^{\circ} \mathrm{C}\right)$. In contrast, the experimental design used in the present study aimed to mimic realistic environmental conditions that are potentially experienced by euryhaline species during their growth season in the estuarine environments of western Europe. Thus, the small increase in temperature from 17 to $21{ }^{\circ} \mathrm{C}$ was potentially not enough to induce an effect/metabolic change for the seabass. Nevertheless, the proposed protocol allowed the effect of the increased temperature on the mullets to be detected, which suggests that seabass may be more eurythermic than mullets in this temperature range mimicking a realistic increase in temperature.

For both species, the lack of interaction between the salinity and temperature may be the result of their good osmotic ability. Thus, they can bear the addition of a second penalising factor, e.g. temperature in the present case. 
Although incursions into freshwater are facultative, they remain a major life history trait for mullets and seabass. For instance, in routine scientific surveys, juveniles, sub-adults, and adults of thicklip mullets and European seabass are caught in brackish estuarine plumes with sometimes very low salinities of around 5. The effect of an abrupt salinity decrease on juvenile European seabass was observed in laboratory simulations, but only during the first day after the salinity change (Conides and Glamuzina, 2006). From the seventh day after the change, the behaviour was again similar to the initial one. The daily growth rate of juvenile European seabass has been described as being higher at salinities above 28 (Conides and Glamuzina, 2006). However, when the temperature is low (around $15{ }^{\circ} \mathrm{C}$ ), a salinity of around 15 allows the highest growth rates in European seabass juveniles (Conides and Glamuzina, 2006). Then, the question of the advantage to marine fish to reach freshwater is still open. For catadromous European eels, freshwater habitats are generally less risky than marine ecosystems in terms of predation (Jonsson and Jonsson, 1993). Some similar life history traits between seabass and eels (both top predators, euryhalines) have led to the assumption that the predation pressure is also lower in freshwater areas for sub-adult seabass. The use of freshwater and brackish areas for feeding by some individuals, mainly juvenile, may lead to a lower conspecific density as a result of population diffusion processes and then increased access to food. Both assumptions can explain the freshwater intrusions by these two euryhaline species, even though extra energy consumption is required. Then, global climate change can limit the biological interest of euryhaline species in feeding in estuaries by modifying the energetic tradeoff.

Finally, these first experimental results suggest that, even if both species are 
flexible enough to face future predicted environmental changes, the extra energy requirements to face temperature and salinity regime modification would probably have consequences on their use of estuarine plumes. It can be hypothesised that the ecological optima for both species would no longer fit expected future conditions, which may lead to a geographical change in their distribution.

With increasing temperature and the extension of freshwater and brackish plumes, seabass may be forced to move toward the sea in more saline habitats. However, with their adaption to temperature in the studied range, seabass may stay in the same local areas with a similar temperature range. In this manner, the main part of their energy could be used for osmotic adaptation. In contrast, for the distribution of thicklip mullets, the results suggest that the temperature is a structuring factor. Their lower acclimation ability to temperature change may lead to latitudinal movements in order for them to stay in their optimal temperature range. In this manner, the main part of their energy may be used for osmotic adaptation, which would allow freshwater incursion to still be possible.

Consider for instance the case of the Loire river, which is the most important river in France and is located along the middle of the Atlantic coast. The temperature is expected to increase by about $2-4{ }^{\circ} \mathrm{C}$ (Bustillo et al. 2014) in 2100 , which is the range used in the present study between the two target temperatures $\left(17\right.$ and $21^{\circ} \mathrm{C}$ ). Vidal et al. (in prep.) showed that, regarding the present, the delta of precipitation will range from -50 (during summer and fall) to $+50 \mathrm{~mm}$ (during winter and spring), which can lead to severe salinity falls in estuaries during the first part of year.

In this context, it is likely that the use of estuarine plumes will require more and more energy from both fish species in the near future. One option to reduce 
the extra energy requirement to face salinity and temperature changes would be for mullets to move towards northern cooler estuaries (e.g., rivers in Britain), and for seabass to move towards more marine areas at least in winters and springs, which would decrease their use of the upper estuary. In the long-term, this assumption cmay lead to a loss of sympatry between these two species. Moreover, these different reactions to environmental changes may lead to the current speciation, as recently observed for seabass (Tine et al., 2014). Tine et al. 2014.

Finally, according to the fish physiology results observed here and the expected model salinity and temperature regimes (IPCC, 2014), a possible scenario could be (i) a decrease of thicklip mullet in the southern part of its distribution area,(ii) no major changes in the middle range of distribution areas, and (iii) an increase of the abundance of the species in the northern areas. For the seabass, the same scenario could occur whatever the latitude: a seasonal shift towards marine areas.

\section{ACKNOWLEDGEMENTS}

The authors sincerely thank Ms. P. Trinh and Dr. A. Lizé for their technical help during the experiments, and Mr. V. Vianet and Mr. S. Aubin for their help during the fishing surveys.

\section{References}

R Development Core, R: A language and environment for statistical computing, 2011. URL http://www.R-project.org.

K. W. Able. Measures of juvenile fish habitat quality: Examples from a national 
estuarine research reserve. American fishery society symposium, 22:134-147, 1999.

J. H. S. Blaxter. Swimming speeds of fish. FAO Fisheries Report, 2(62), 1969.

Vincent Bustillo, Florentina Moatar, Agnes Ducharne, Dominique Thierry, and Alain Poirel. A multimodel comparison for assessing water temperatures under changing climate conditions via the equilibrium temperature concept: case study of the middle loire river, france, 2014. URL http://dx.doi.org/ 10.1002/hyp.9683

Luis Cardona, Bernat Hereu, and Xavier Torras. Juvenile bottlenecks and salinity shape grey mullet assemblages in mediterranean estuaries. Estuarine, Coastal and Shelf Science, 77(4):623-632, 2008. doi: http://dx.doi.org/10. 1016/j.ecss.2007.10.018. URL http://www.sciencedirect.com/science/ article/pii/S0272771407004891.

A. Carpentier, S. Como, C. Dupuy, C. Lefrancois, and E. Feunteun. Feeding ecology of Liza spp. in a tidal flat: Evidence of the importance of primary production (biofilm) and associated meiofauna. Journal of Sea Research, 92:86-91, 2014. doi: 10.1016/j.seares.2013.10.007. URL <GotoISI>://WOS: 000342478100011

A. Chatelier, D. McKenzie, and G. Claireaux. Effects of changes in water salinity upon exercise and cardiac performance in the european seabass $(D i$ centrarchus labrax). Marine Biology, 147(4):855-862, 2005. doi: 10.1007/ s00227-005-1624-7. URL <GotoISI>://WOS:000230963900003.

S. Como, C. Lefrancois, E. Maggi, F. Antognarelli, and C. Dupuy. Behavioral responses of juvenile golden gray mullet Liza aurata to changes in coastal temperatures and consequences for benthic food resources. Journal 
of Sea Research, 92(0):66-73, 2014. doi: http://dx.doi.org/10.1016/j.seares.

2013.10.004. URL http://www.sciencedirect.com/science/article/ pii/S1385110113001986

A. J. Conides and B. Glamuzina. Laboratory simulation of the effects of environmental salinity on acclimation, feeding and growth of wild-caught juveniles of european sea bass Dicentrarchus labrax and gilthead sea bream, Sparus aurata. Aquaculture, 256(1-4):235-245, 2006. doi: 10.1016/j.aquaculture.2006. 02.029. URL <GotoISI>://WOS:000238394400026.

J. Dalla Via, P. Villani, E. Gasteiger, and H. Niederstatter. Oxygen consumption in sea bass fingerling dicentrarchus labrax exposed to acute salinity and temperature changes: metabolic basis for maximum stocking density estimations. Aquaculture, 169(3-4):303-313, 1998. doi: 10.1016/s0044-8486(98)00375-5. URL <GotoISI> : //WOS : 000077546100014.

M. Elliott and F. Dewailly. The structure and components of european estuarine fish assemblages. Netherlands Journal of Aquatic Ecology, 29(2-3):397-417, 1995.

L. Ferrer, A. Fontan, J. Mader, G. Chust, M. Gonzalez, V. Valencia, A. Uriarte, and M. B. Collins. Low-salinity plumes in the oceanic region of the basque country. Continental Shelf Research, 29(8):970-984, 2009. doi: 10.1016/j.csr. 2008.12.014. URL <GotoISI> ://WOS: 000266057100003.

E. Feunteun, C. Rigaud, P. Elie, and J. C. Lefeuvre. Les peuplements piscicoles des marais littoraux endigues atlantiques. le cas du marais de bourgneuf machecoul (loire-atlantique, france). (352):63-79, 1999. URL http://dx.doi.org/10.1051/kmae:1999021.

P. Franzoi, A. Franco, and P. Torricelli. Fish assemblage diversity and dynamics in the venice lagoon. Rendiconti Lincei-Scienze Fisiche E Naturali, 21(3): 
269-281, 2010. doi: 10.1007/s12210-010-0079-z. URL <GotoISI> ://WOS : 000281762700005

Dominique Gautier and Jerome Hussenot. Les mulets des mers d'Europe : synthese des connaissances sur les bases biologiques et les techniques d'aquaculture. Ifremer, Plouzane, France, 2005.

R. N. Gibson. Impact of habitat quality and quantity on the recruitment of juvenile flatfishes. Netherlands Journal of Sea Research, 32(2):191206, 1994. URL http://www.scopus.com/inward/record.url?eid=2-s2. 0-0028607789\&partnerID $=40 \& m d 5=f 7 c 1 b b b 78$ ef 1 e812f c6c530a3262aac 7 .

J. J. Grover, T. W. Buckley, and D. Woodbury. Effects of the 1997-1998 el nino on early-juvenile pacific hake merluccius productus: age, growth, abundance, and diet in coastal nursery habitats. Marine Ecology Progress Series, 240:235-247, 2002. doi: 10.3354/meps240235. URL <GotoISI>://WOS: 000178457600022

S. J. Holbrook, G. E. Forrester, and R. J. Schmitt. Spatial patterns in abundance of a damselfish reflect availability of suitable habitat. Oecologia, 122(1):109-120, 2000. doi: 10.1007/pl00008826. URL <GotoISI>://WOS: 000084946900014

IPCC. Summary for policymakers. In C. B. Field, V. R. Barros, D. J. Dokken, K. J. Mach, M. D. Mastrandrea, T. E. Bilir, M. Chatterjee, K. L. Ebi, Y. O. Estrada, R. C. Genova, B. Girma, E. S. Kissel, A. N. Levy, S. MacCracken, P. R. Mastrandrea, and L. L. White, editors, Climate Change 2014: Impacts, Adaptation, and Vulnerability. Part A: Global and Sectoral Aspects. Contribution of Working Group II to the Fifth Assessment Report of the Intergovernmental Panel on Climate Change, pages 1-32. Cambridge University Press, Cambridge, United Kingdom, and New York, NY, USA, 2014. 
G. P. Jenkins, K. P. Black, M. J. Wheatley, and D. N. Hatton. Temporal and spatial variability in recruitment of a temperate, seagrass-associated fish is largely determined by physical processes in the pre- and post-settlement phases. Marine Ecology Progress Series, 148(1-3):23-35, 1997. doi: 10.3354/ meps148023. URL <GotoISI>://WOS:A1997WW71400003.

B. Jonsson and N. Jonsson. Partial migration - niche shift versus sexualmaturation in fishes. Reviews in Fish Biology and Fisheries, 3(4):348-365, 1993. doi: 10.1007/bf00043384. URL <GotoISI>://WOS :A1993MN30200002.

D. F. Kelley, M. G. Pawson, G. D. Pickett, and D. F. Kelley. The distribution and migrations of bass, Dicentrarchus labrax L., in waters around england and wales as shown by tagging. Journal of the Marine Biological Association of the United Kingdom, 67(01):183-217, 1987. doi: 10.1017/S0025315400026448. URL http://dx.doi.org/10.1017/S0025315400026448

B. A. Kelly-Gerreyn, D. J. Hydes, A. M. Jegou, P. Lazure, L. J. Fernand, I. Puillat, and C. Garcia-Soto. Low salinity intrusions in the western english channel. Continental Shelf Research, 26(11):1241-1257, 2006. doi: 10.1016/ j.csr.2006.03.007. URL <GotoISI>://WOS:000239261900001.

M. Kottelat. The correct name of the thinlip mullet (Liza ramada) (teleostei: Mugilidae). Ichthyological Exploration of Freshwaters, 19(3):243244, 2008. URL http://www.scopus.com/inward/record.url?eid=2-s2. $0-57649088546 \&$ partnerID $=40$.

P. Laffaille, J. C. Lefeuvre, M. T. Schricke, and E. Feunteun. Feeding ecology of o-group sea bass, Dicentrarchus labrax, in salt marshes of mont saint michel bay (France). Estuaries, 24(1):116-125, 2001a. doi: 10.2307/1352818. URL http://dx.doi.org/10.2307/1352818. 
P. Laffaille, L. Thieulle, E. Feunteun, and J. C. Lefeuvre. Composition du peuplement piscicole d'un petit estuaire anthropise (le Couesnon, France). Bulletin francais de la peche et de la pisciculture, (357-360):191-208, 2001b. URL http://dx.doi.org/10.1051/kmae/2001044

Pierre Lasserre and Jean-Louis Gallis. Osmoregulation and differential penetration of two grey mullets, Chelon labrosus (Risso) and Liza ramada (Risso) in estuarine fish ponds. 344, 1975. URL http://www.sciencedirect.com/science/article/ B6T4D-49NPJR6-V3/2/2565789b9cfcd94d289601e106791bb4

O. Le Pape, F. Chauvet, S. Mahevas, P. Lazure, D. Guerault, and Y. Desaunay. Quantitative description of habitat suitability for the juvenile common sole (Solea solea, L.) in the bay of biscay (France) and the contribution of different habitats to the adult population. Journal of Sea Research, 50(2-3):139149, 2003. doi: 10.1016/s1385-1101(03)00059-5. URL <GotoISI>://WOS: 000186381600006

Bernhard Lehner, Petra Doll, Joseph Alcamo, Thomas Henrichs, and Frank Kaspar. Estimating the impact of global change on flood and drought risks in europe: A continental, integrated analysis. Climatic Change, 75(3):273-299, 2006. doi: 10.1007/s10584-006-6338-4. URL http://dx.doi.org/10.1007/ s10584-006-6338-4.

E. Macpherson and C. M. Duarte. Bathymetric trends in demersal fish size - is there a general relationship? Marine Ecology Progress Series, 71(2):103-112, 1991. doi: 10.3354/meps071103. URL <GotoISI>://WOS:A1991FG53400001.

Peter S. Maitland and Alex A. Lyle. Conservation of freshwater fish in the british isles: The current status and biology of threatened species. 1(1):25- 
54, 1991. doi: 10.1002/aqc.3270010104. URL http://dx.doi.org/10.1002/ aqc.3270010104.

R. M. McDowall. The occurrence and distribution of diadromy among fishes. American Fisheries Society Symposium, 1:1-13, 1987.

R. M. McDowall. Diadromy in fishes: migration between freshwater and marine environments. Croom Helm, London, 1988.

R. M. McDowall. The evolution of diadromy in fishes (revisited) and its place in phylogenetic analysis. Reviews in Fish Biology and Fisheries, 7(4):443462, 1997. URL http://www. scopus. com/inward/record.url?eid=2-s2. 0-0001744869\&partnerID $=40 \& m d 5=57 d 089$ ec93b88bad3ac92f090f $6 \mathrm{f} 226 \mathrm{a}$

JohnM Miller, JamesP Reed, and LeonardJ Pietrafesa. Patterns, mechanisms and approaches to the study of migrations of estuarine-dependent fish larvae and juveniles. In JamesD McCleave, GeoffreyP Arnold, JulianJ Dodson, and WilliamH Neill, editors, Mechanisms of Migration in Fishes, volume 14, pages 209-225. Springer US, 1984. doi: 10.1007/978-1-4613-2763-9_14. URL http: //dx.doi.org/10.1007/978-1-4613-2763-9_14

J. A. Nelson and G. Claireaux. Sprint swimming performance of juvenile european sea bass. Transactions of the American Fisheries Society, 134 (5):1274-1284, 2005. doi: 10.1577/t04-087.1. URL <GotoISI>://WOS : 000232737300018

D. Nicolas, J. Lobry, O. Le Pape, and P. Boet. Functional diversity in european estuaries: Relating the composition of fish assemblages to the abiotic environment, 2010. URL <GotoISI>://WOS:000279537500004.

M. G. Pawson, G. D. Pickett, and D. F. Kelley. The distribution and migrations of bass, Dicentrarchus labrax L., in waters around england and wales as shown 
by tagging. 67(01):183-217, 1987. doi: 10.1017/S0025315400026448. URL http://dx.doi.org/10.1017/S0025315400026448.

M. S. Peterson. A conceptual view of environment-habitat-production linkages in tidal river estuaries. Reviews in Fisheries Science, 11(4):291-313, 2003. doi: 10.1080/10641260390255844. URL <GotoISI> : //WOS : 000187669400001

G. D. Pickett and M. G. Pawson, editors. European Seabass. Chapman and Hall, London, 1996.

S. Rochette, E. Rivot, J. Morin, S. Mackinson, P. Riou, and O. Le Pape. Effect of nursery habitat degradation on flatfish population: Application to Solea solea in the eastern channel (Western Europe). Journal of Sea Research, 64(1-2): 34-44, 2010. doi: http://dx.doi.org/10.1016/j.seares.2009.08.003. URL http: //wWw.sciencedirect.com/science/article/pii/S1385110109000768.

G. M. Ruiz, A. H. Hines, and M. H. Posey. Shallow-water as a refuge habitat for fish and crustaceans in nonvegetated estuaries - an example from chesapeake bay. Marine Ecology Progress Series, 99(1-2):1-16, 1993. doi: 10.3354/meps099001. URL <GotoISI> : //WOS : A1993LY00300001.

F. J Sanchez Vazquez and J. A. Munoz-Cueto, editors. Biology of European Sea Bass. CRC Press, 2014.

M. Tine, H. Kuhl, P. A. Gagnaire, B. Louro, E. Desmarais, R. S. T. Martins, J. Hecht, F. Knaust, K. Belkhir, S. Klages, R. Dieterich, K. Stueber, F. Piferrer, B. Guinand, N. Bierne, F. A. M. Volckaert, L. Bargelloni, D. M. Power, F. Bonhomme, A. V. M. Canario, and R. Reinhardt. European sea bass genome and its variation provide insights into adaptation to euryhalinity and speciation. Nature Communications, 5, 2014. doi: 577010.1038/ncomms6770. URL <GotoISI> : //WOS : 000347175200001. 
G. van den Thillart, V. van Ginneken, F. Korner, R. Heijmans, R. van der Linden, and A. Gluvers. Endurance swimming of european eel. Journal of Fish Biology, 65(2):312-318, 2004. URL http://wWw.sciencedirect.com/science/article/B6WW2-4D74JTW-3YM/ 2/0607c523e86fcd7a3146cf4115e9e4ee. 